\title{
Controlling módszerek ismerete és alkalmazásuk az Észak-alföldi régió kis- és középvállalkozásainak gyakorlatában
}

\section{Knowledge of Control Methods and their Application in the Practice of Small and Medium Enterprises in the Northern Great Plain Region}

\author{
V. LAKATos ${ }^{1}$, B. Béresné Mártha², G. Tömöri ${ }^{3}$ \\ ${ }^{1}$ Debreceni Egyetem, Gazdaságtudományi Kar, Számviteli és ,Pénzügyi Intézet lakatos.vilmos@econ.unideb.hu \\ ${ }^{2}$ Debreceni Egyetem, Gazdaságtudományi Kar, Számviteli és,Pénzügyi Intézet \\ beresne.martha.bernadett@econ.unideb.hu \\ ${ }^{3}$ Debreceni Egyetem, Gazdaságtudományi Kar, Számviteli és,Pénzügyi Intézet tomori.gergo@econ.unideb.hu
}

\begin{abstract}
Absztrakt. A nagyvállalatokhoz hasonlóan a kis- és középvállalkozói kör is igényli mindazokat az információkat, amelyek a vállalkozási tevékenység eredményességét és hatékonyságát tudják biztosítani az általuk hozott megalapozott vezetöi döntésekkel. A nagyvállalatokhoz képest a kkv-k jelentős fejlödési potenciállal rendelkeznek, amelyet részben maguk a vállalkozások ki tudnak alakítani esetlegesen új-modern menedzsmenti - üzleti adminsztrációs módszerek bevezetésével, illetve gazdaságpolitikai intézkedések révén (=célzott és hatékony támogatási rendszerrel) lehetôvé válhat számukra az a finanszírozási forrástömeg, amely a $K+F+I$ folyamatok gerjesztésével szolgálja a versenyképesség növekedését és a hazai GDP-hez, exporthoz való nagyobb mértékú és arányú hozzájárulásukat. A tanulmányban bemutatásra kerülö elemzésben kitérünk a vizsgálati körbe bevont Északalföldi régióba tartozó kkv-k kvezetöinek controlling ismereteire, a controlling eszközök tudatos vagy éppen nem tudatos alkalmazására, az utódlás megítélésére, a vevői és beszállitói értékelésre és a vezetői számvitel egyes területeire. Összességében megállapítható a kis elemszámú minta alapján is, hogy a controlling eszközök használata arányos a vállalkozási mérettel, de ennek ellenére sok közepes méretú vállalkozás vezetöje nem igényli a belsó információk olyan mértékű gyüjtését és elemzését, amely kifejezetten tudná segíteni a döntéselőkészítés hatékonyságát, pl. a korszerű önköltségszámítási eljárások révén.
\end{abstract}

Abstract. Like large companies, the small, and medium-sized businesses need also all the information to ensure the efficiency and effectiveness of their business by making sound management decisions. Compared to large companies, SMEs have significant development potential, which can be created in part by the companies themselves, possibly through the introduction of new-modern management - business administration methods or economic policy measures (= targeted and efficient support system), which, by stimulating $R \& D \&$ I processes, serves to increase competitiveness and contribute more and proportionally to domestic GDP and exports. The analysis presented in the 
study covers the controlling knowledge of the leading SMEs of the Northern Great Plain Region, the conscious or unconscious application of controlling tools, the assessment of succession, customer and supplier valuation and certain areas of managerial accounting. Overall, it can be concluded from the small sample size that the use of controlling tools is proportional to the size of the business, but nevertheless, many mid-size business executives do not require the collection and analysis of insider information that could explicitly help decision making for example through advanced costing procedures.

\section{Bevezetés}

A vállalkozások többsége keresi azon kockázatok elkerülési, illetve csökkentési lehetőségét, amelyek a tevékenységük környezetéből és belső feltételrendszeréből folyamatosan megjelennek. A külső környezet gazdasági, társadalmi, ökológiai, politikai és technikai változásai is állandó változásuk miatt állítanak kihívást a vállalkozásvezetők elé, amelyet időben és érdemben kell kezelniük. A controlling, mint a vállalkozás vezetésének eszközrendszere biztosítani képes azokat a módszereket, amelyekkel a tervezés és elemzés révén csökkenthetők a tevékenység kockázatai, s ezzel együtt a növelhető a vállalat értéke akár számviteli- akár gazdasági értelemben.

A fenti okok miatt az elmúlt évtizedekben nemzetközi viszonylatban is többen foglalkoztak-foglalkoznak a controlling módszerek vállalatokban betöltött szerepével, azok megítélésével és alkalmazásuk elemzésével. A kis- és középvállalkozások - vagyis azok a társaságok, ahol az összes foglalkoztatott létszáma 250 főnél kevesebb és az éves nettó árbevétel legfeljebb 50 millió eurónak megfelelő forintösszeg, vagy a mérlegfőösszeg legfeljebb 43 millió eurónak megfelelő forintösszeg - a mintegy 718 ezres létszámukkal a teljes magyar vállalati kör 99 százalékát adják. (KSH, 2017.) A működő vállalkozások összteljesítményéhez a hozzáadott érték 44, a nettó árbevétel 42, a nemzetgazdasági beruházások 31 százalékával járulnak hozzá a kkv-k. A kkv-szektor a vállalati szférában dolgozók mintegy 70 százalékát foglalkoztatja, összesen mintegy kétmillió fót. A számok alapján világosan látszik, hogy a kkv-szektor egy nagyon markáns és széles tömeget jelent, de ezek a cégek a nagy, jellemzően multinacionális vállalatoktól jelentősen elmaradó hatékonyságot mutatnak, így bőven lehet tere az előrelépésnek. (Horváth, Kovács, Ella 2019.) Ennek következtében különösen fontos e vállalati körnek a menedzsmenti jellegű fejlesztése, amely további fejlődési potenciált hordozhat magában (Veresné, 2013), részben azért is, mert a kkv- körben a nagyvállalati szinthez mérve fejleszthető mind a hatékonyság, mind az eredményesség, s ez tovább javíthat a gazdasági növekedésen, hozzájárulhat a társadalom erősítéséhez, valamint az export és import arányához. (Zéman és Lentner, 2018, Vadász, 2019.)

\section{A kis- és középvállalkozások jellemzői Magyarországon}

A bevezetésben említett számszerű tényezőkön felül több ismérve is "kifejlődött" a hazai kkv szektornak a rendszerváltás óta, amikor is megjelentek a jelenleg is múködő vállalkozások, valamint azok jogelődjei. Az aktuális gazdaságpolitika nem véletlenül kíván hathatósabb eszközökkel e vállalkozási méretkörbe segítőleg beavatkozni, hiszen van bennük fejlődési potenciál, amely sok esetben nem feltélenül 
technikai-technológiai korszerűsítést igényel, hanem modern menedzsmenti-gazdálkodási mószerek, így controlling eszközök bevezetését feltételezi (Fenyves és Tarnóczi, 2019, Fenyves 2019).

\subsection{A kis- és középvállalkozások fejlesztendő területei}

A magyar kkv szektor problémái a következőkben foglalható össze (Horváth, Kovács, Ella 2019.)

1. Gyenge hatékonyság: egy átlagos magyar kkv termelékenysége mindössze egyharmada a nagyvállalatoknál regisztrált szintnek.

2. Elégtelen beruházási ráta: A magyar kkv-k nem elég tőkeintenzívek, az alacsony beruházási ráta - és ezen belül a technológiai, termelékenységet növelő beruházások alacsony részaránya - konzerválja az elavult termelési rendszereket és így a lemaradást az élvonalhoz képest.

3. Mérsékelt kutatási és innovációs teljesítmény: a kkv-k jelentős részénél hiányzik az innovációhoz szükséges tudás és a tőke, sőt létezik egyfajta bizalmatlanság is, hogy kihez fordulhatnának a tudás megszerzéséért. Nagyon kevés kkv használ korszerű vállalatirányítási szoftvereket, sőt: minden ötödik vállalkozásnak még honlapja sincsen.

4. Alacsony bérszínvonal, aminek nyomán a képzett és tapasztalt munkaerőhöz való hozzáférés is korlátozott. A munkaerő Nyugat-Európába történő elvándorlása - ami Magyarország esetében nem kiugróan magas, mintegy 600 ezer főre tehető - a kkv-szektort sújtotta leginkább. A humánerőforrás minőségét javíthatnák a vállalati továbbképzések, de ez nem jellemző a kkv-kra.

5. Jelentős hátrányt szenvednek kis méretük és ebből kifolyólag kicsiny gazdasági erejük miatt: ártárgyalásokon, akár a végtermék, akár az alapanyagok esetében rossz alkupozíció, korlátozott hozzáférés a tőkepiacokhoz, nehézkes az ügyfélszerzés.

6. Az idősödő cégvezetés és a generációváltás kiemelt probléma: a hazai vállalkozások közel 20 százaléka esetében a legfiatalabb tulajdonos is már 60 év feletti. ami azt jelenti, hogy a generációváltás problémája néhány éven belül fokozódni fog. Az is jellemző továbbá, hogy a családi vállalkozások több mint 70 százaléka úgy képzeli el az utódlást, hogy az ügyvezetési feladatokat egy családtagnak adja át. Rudas László, a Családi Vállalkozások Országos Egyesületének elnöke ennek kapcsán a közelmúltban hangsúlyozta: "Nyugat-Európában minden harmadik cég éli csak túl a generációváltást, amely arány Magyarországon akár még rosszabb is lehet, tekintettel a gyengébb vállalkozói kultúrára."

7. Magyarországon a cégtulajdonosi és a menedzseri munkakör nem vált el, vagyis jellemzően azok irányítják a kkv-kat, akik alapították. Ezek a cégek időközben vállalati méreteket vettek fel, ugyanakkor irányítási modelljük megmaradt egy induló vállalkozás szintjén. A képzett menedzsment hiánya rontja a versenyképességet és korlátozza vállalati életciklus-modellen belüli továbblépés lehetőségeit. Ennek egyik következménye, hogy a Budapest LAB kutatása szerint az elmúlt években a kkv-k csupán mintegy 29 százaléka tört be új piacokra és 60 százalékuk semmilyen exporttevékenységet nem végez. 
8. Hiányos vállalatépítési kompetenciák: ahhoz, hogy a nagyra nőtt családi vállalkozások valódi vállalattá fejlődjenek, tudatos fejlesztésre van szükség, az ehhez szükséges tudással és tapasztalattal azonban a legritkább esetben rendelkeznek az alapító-tulajdonosok. Az ilyen jellegű fejlesztési tevékenységek komplex megközelítést kívánnak a jövőkép- és stratégiaalkotástól egészen a végrehajtásig. Sajnos kevés olyan külső szakértő vonható be ebbe a folyamatba, akik rendelkeznek a szükséges tapasztalatokkal, továbbá a bizalom korlátozott az ilyen jellegű külső segítség iránt.

9. Az állami és uniós támogatási rendszer hiányosságai: a nagyobb cégekhez képest a kkv-k kifejezetten nehezen érik el a finanszírozási forrásokat. Elméleti szinten számos pénzügyi forrás áll rendelkezésükre, azonban csak a belföldi pénzügyi intézetektől származó hitelek, és az uniós támogatással nyújtott vissza nem térítendő támogatások játszanak meghatározó szerepet. Ki kell emelni tovább a Magyar Nemzeti Bank hitelprogramjait.

10. Magas közterhek és adminisztrációs terhek: a kkv-k közterhei magasabbak a nagyvállalatok terheinél, illetve az adminisztrációval töltött idő is túl magas. Továbbá a nagy és multinacionális vállalatoknak jelentősen kedveznek a kormányzati munkahely-teremtési támogatások is.

\subsection{A kis- és középvállalkozások fejlesztési lehetőségei}

A fejlesztendő területek definiálása részben magában hordozza a fejlesztési lehetőségek meghatározását is, hiszen több esetben ehhez nem feltétlenül szükséges sem pénzügyi forrás, sem technológiai fejlesztés, hanem inkább szemléletbeli és attitüd váltással érhetők el menedzsmenti területen fejlődést előídéző beavatkozások. Természetesen akár ezeket, akár a külső finanszírozási forrásokat igénylő akciókat ösztönözni - gerjeszteni szükséges, amely hatékonyabb, ha ezt a vállalkozás külső - gazdaságpolitikai- környezetéből kezdeményezik. Mit tehet az állam annak érekében, hogy javuljon a magyar kkv-szektor termelékenysége, további lökést adva ezzel a magyar gazdaság szekerének?

A lehetséges akciókat a következókben lehet összefoglani (Horváth, Kovács, Ella 2019.)

1. A munkahelyteremtő beruházások helyet a termelékenységet javító, technológiai beruházások és tudásintenzív ágazatok támogatása. Ahogy arra az Állami Számvevőszék nemrég publikált tanulmánya rámutatott: a munkaerőpiac jelenlegi helyzete már nem indokolja az egyedi munkahelyteremtés közpénzből való további ösztönzését, ehelyett a tudásintenzív, magas hozzáadott értékkel bíró ipari és szolgáltatási ágazatokat érdemes támogatni. Ez egy átállás lenne a beruházásvezérelt modellről az innovációvezérelt modellre.

2. A szintugrást, vállalatépítést megcélzó kezdeményezések és tanácsadói erőfeszítések támogatása. Svéd példa alapján a kkv-k kaphatnának olyan vouchert, amelyet tanácsadói szolgáltatásra válthatnak be a vállalatépítés elősegítésére.

3. Az utódlást támogató vállalatfejlesztési programok szakértői támogatásának finanszírozása és támogatása. A generációváltás problémája támogatható különböző motivációs eszközökkel. 
4. Szakképzési rendszer átalakítása a munkaerő-piaci folyamatokhoz.

5. Adókedvezmények bevezetése, technológiai és versenyképességet javító beruházások esetén.

6. A kkv-k adminisztrációs terheinek célzott csökkentése. Ezen a területen számos előrelépés történt az elmúlt években.

7. Foglalkozási, ágazati differenciált minimálbér kialakítása.

\subsection{Méret a lényeg! Avagy vállalkozásból vállalatok!}

A szakértők szerint sok induló sikeres kisvállalkozásnál eljön az a fordulópont, amikor a tulajdonosmenedzser már nem képes a hagyományos vállalkozásirányítási módszerekkel működtetni a cégét, de ezt sokan nem veszik tudomásul és ez lehet az igazi gátja a további fejlődésnek. Természetesen van több lehetőség felkészülni a vállalattá válásra, sőt egy stratégiát alkotó kis-középvállalkozás ezt tudatosan tervezi is, de ebben az esetben is lehetnek olyan szubjektív tényezők, amelyeket fel kell oldani a hosszú távú fejlődés érdekében.

Ilyen az utódlás tervezése: ésszerű, de ritka helyzet, amikor a családon belüli utód legalább annyira elkötelezett és alkalmas a cégvezetésbe történő bevonódásra, mint a felmenő generáció (Tobak et al., 2018). A magántulajdonú vállalkozások esetén hazánkban legfeljebb 1/5-e az utódok aránya, akik tudatosan készek átvenni a vállalkozás irányítását! A vállalatépítés szintén törekvése kell, hogy legyen a menedzsmentnek, s ki kell fejleszteni a méret növekedésekor az adekvát szervezeti egységeket, kellő felelősséggel ellétva azok vezetőit, ezáltal részben függetleníteni a tulajdonosi szerepkört a vezetőitől. Ehhez tapasztalattal rendelkező szakemberek is szükségesek, akik át tudják vezetni a céget ezeken a fejlődési fázisokon. A korábban említett kismértékű egyenesági utodlás velejárója a cégértékesítés, de nem mindegy ebben az esetben, hogy egy kézivezérelt vállalkozást vagy egy jól menedzselt, felelősségi központokkal működő céget kíván-e eladni a tulajdonosa. A kettő között akár 50\%-os értékkülönbözet is lehet, s ez akár több 10-100 millió forintos eltérést jelenthet az eladási árban, így a tulajdonosnak akár az utódlástól függetlenül is - érdemes a független -felelős menedzsmentű irányítást kialakítania.

\section{Anyag és módszer}

A kis- és középvállalkozások controlling jellegzetességeinek elemzése statisztikai adatbázisok alapján kevésbé lehetséges, hiszen a tervezési, terv-tény elemzési, önköltség-számítási és egyéb vezetői számviteli jellemzőkről nincs nagy elemszámú mintára vonatkozó adatbázis. Ennek következtében közvetlen adatgyűjtéssel - kérdőíves felvételezéssel lehetséges olyan jellemzőkhöz jutni, amely alapján elemzéseket lehet lefolytatni, s akkor is kétséges azok egy adott időpontra vonatkozó reprezentatív jellege. Másrészt problémás idősoros elemzéseket is megtenni, hiszen nem garantált ugyanannak a vállalkozói körnek a következő években történő bevonhatósága azok megszűnése, adatszolgáltatási hajlandóságuknak, a menedzsmenti -tulajdonosi kör változása miatt.

Vizsgálatainkban tehát egy több éves előzménnyel bíró módszertannal folytattunk kérdőíves adatfelvételezést a vállalkozások controlling sajátosságairól, amelynek lényegi eleme a közvetlen 
kapcsolat létesítése a vállalkozások illetékeseivel, akik akár részletes információkkal is tudnak szolgálni a vezetői döntéselőkészítéshez kapcsolódó controlling jellegű folyamatokról.

Kérdőíves feldolgozás keretében 2019 őszén begyűjtött adatok alapján összesen 70, az Észak-alföldi régió megyéiben székhellyel rendelkező, zömében kis- és középvállalkozások tervezésivállalkozásvezetési sajátosságait mértük fel. A vállalkozók nagy aránya törekszik a tevékenységének kockázatcsökkentésére, amelynek eszközeiként több általuk is ismert, de önállóan már csak kis mértékben alkalmazott módszert említenek. A döntéstámogató tevékenységek teljes mértékben összekapcsolhatók a még mindig sok cégvezetőnek idegenként ható „controlling” szemlélettel és módszerekkel, amelyek bevezetése és alkalmazása viszonylag rövid időtávon belül kézzel fogható eredményekkel szolgálhatna a vállalkozások döntéshozói számára. A tanulmányban bemutatásra kerülnek a vizsgálatba vont kkv-k méret, tevékenységi kör, pénzügyi folyamat jellemzői, likviditásra, tervezési sajátosságaira, valamint az önköltségszámításra vonatkozó gyakorlatai és összefüggések feltárása a vállalkozási méret és az alkalmazott controlling eszközök között.

A kérdőíves felmérés érintette a vállalkozás (esetleg központjának) megye szerinti elhelyezkedését, méretét (saját elképzelés alapján és ténylegesen besorolva), a tevékenységhez a gazdálkodásimenedzsmenti szaktudás meglétét, az esetleges utódlási lehetőségeket, a vagyoni struktúra jellemzőit, a likviditás helyzet értékelését, a vevői és beszállítói minősítések-értékelések gyakorlatát és egy kérdéscsoport foglalkozott a vállalkozások controlling jellemzőivel: tervezési-elemzési, irányítási és információs folyamataival, majd a költségkalkulációkkal és költségallokációkkal, mely a kis- és középvállalkozások (kkv-k) menedzsmenti tevékenységének továbbra is egyik gyenge láncszemének tekinthető.

\section{Eredmények}

A vizsgálatok első részében a vállalkozások általános adatait mértük fel, majd azt követően a controlling (tervezési, likviditás-vizsgálati, vevő-szállító minősítási és önköltségszámítási) jellegű tevékenységeiket mutattuk ki.

Az elemzésbe bevont 70 vállalkozás székhelye az Észak-alföldi régió három megyéjében az 1 ábra szerinti megoszlásban helyezkedik el.

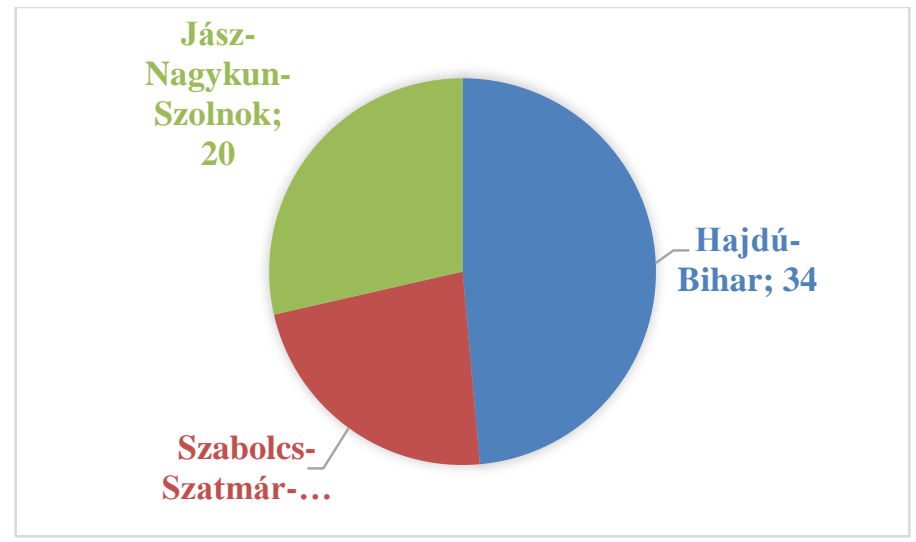

1. ábra. A vállalkozások területi elhelyezkedése, db Forrás: saját elemzés 
A vállalkozások jogi forma szerinti megoszlásában három kategória került megkülönböztetésre a kkvkre vonatkozóan: a betéti társaságok mellett a korlátolt felelősségű társaság és a részvénytársaság is megjelenik. (2.ábra)

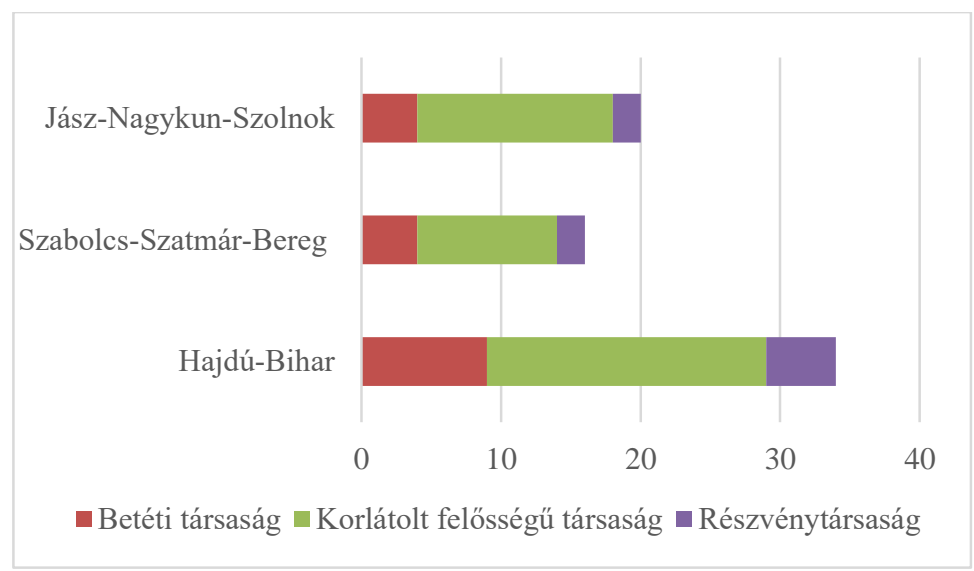

2. ábra. A vállalkozások gazdasági társaság szerinti megoszlása megyénként, db Forrás: saját

Az elemzett vállalkozások körében dominál a kft keretében végzett tevékenység, amely már nagyobb eszközértéket és árbevételt is feltételez a betéti társaságokhoz képest. A részvénytársasági forma is bekerült az elemzésbe, ugyanis azok egy kivétellel szintén a kkv körbe tartoznak

A vállalkozási tevékenységhez természetesen szükség van szakmai hozzáértésre, tapasztalatra és elvárt a megfelelő szakmai végzettség is. A vállalkozások 92\%-nál ez adott volt, a vezetők vagy már a vállalkozás indításakor eleve rendelkeztek szakirányú végzettséggel, vagy a kezdeti múködés során szereztek végzettséget tanúsító bizonyítványt. A szakmai hozzáértést mutatja az a tény is, hogy a menedzserek 54\% -a felsőfokú végzettséggel rendelkezik. A kérdőív rákérdezett a vállalkozás irányításához kapcsolódó szakmai ismeretek meglétére, amely a gazdasági folyamatok tervezési, szervezési, pénzügyi területére vonatkozott, tehát a vállalatirányítási tevékenységre. A helyzet e tekintetben hasonló képet mutat, mint a szakmai hozzáértésnél volt tapasztalható. A menedzserek mindössze 25\%-a szerzett korábban dokumentáltan gazdálkodással összefüggő ismereteket, 38\%-uk vélekedett úgy, hogy a vállalkozáson-családon belül hozzáférhető ez a fajta szaktudás, s mindössze 12\%uk jelezte, hogy nincs és nem is hiányzik nekik az ilyen típusú ismeret. (3.ábra)

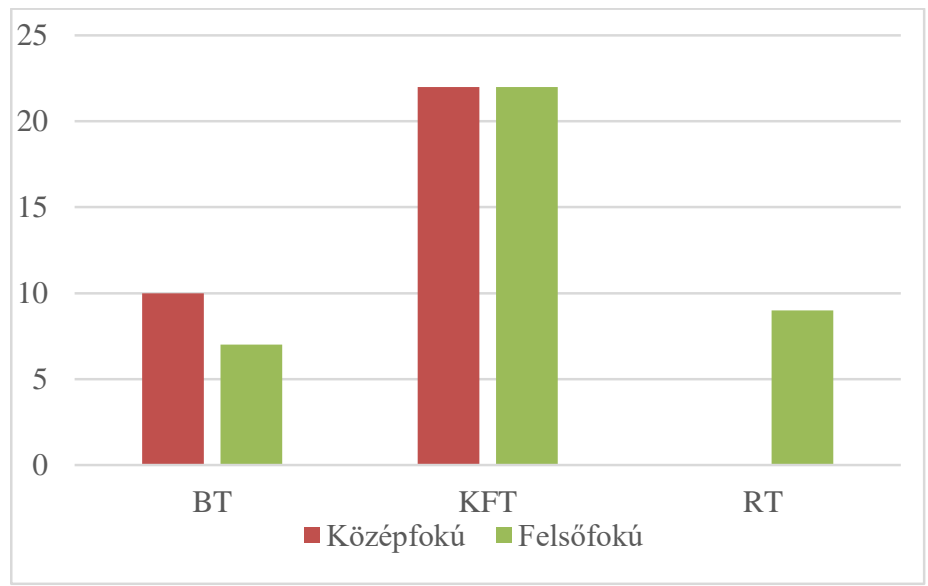

3. ábra A vállalkozásvezetők iskolai végzettség szerinti megoszlása, db Forrás: saját elemzés 
A vállalkozások eltérő tevékenységi körbe sorolhatók, de az árbevétel jelentősebb részét alkotó “fő”tevékenységük alapjána 4. ábra szerinti megoszlást kaptuk:

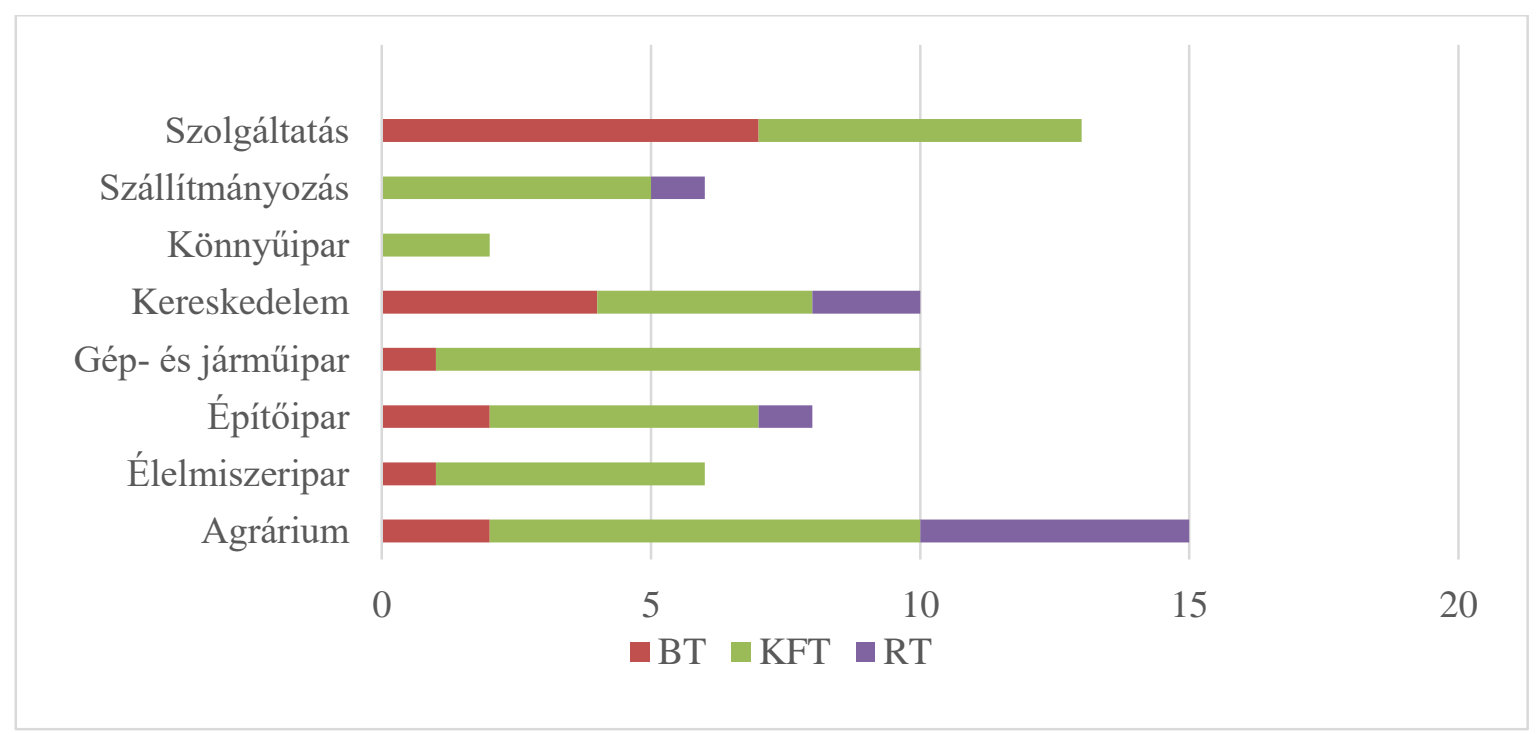

4. ábra. A vállalkozások fötevékenysége szerinti megoszlása, db Forrás: saját elemzés

A 2019 őszi adatfelvételezésbe több mezőgazdasági termelő - elsősorban növénytermesztéssel foglalkozó gazdasági társaság került be, ahol a méretbeli besorolást nehezítette a családtagok tényleges közremúködésének megítélése, így az adatközló vállalkozásvezető közlésére hagyatkoztunk.

Érdekes vizsgálatai elemünk a vezetők által és a tényleges alkalmazotti adatok szerinti méretkategória kimutatása. A korábbi évek elemzései is azt jelzik, hogy a vidéki kisebb települések vállalkozói természetesen nem ismerve a méretkategóriák értékhatárait - nagyobb jelentőséget így nagyobb méretet is tulajdonítanak a vállalkozásuknak, s ez kifejezetten a közepes méretkatógirát magának vélő vállalkozások esetén volt érzékelhető. (5. ábra)

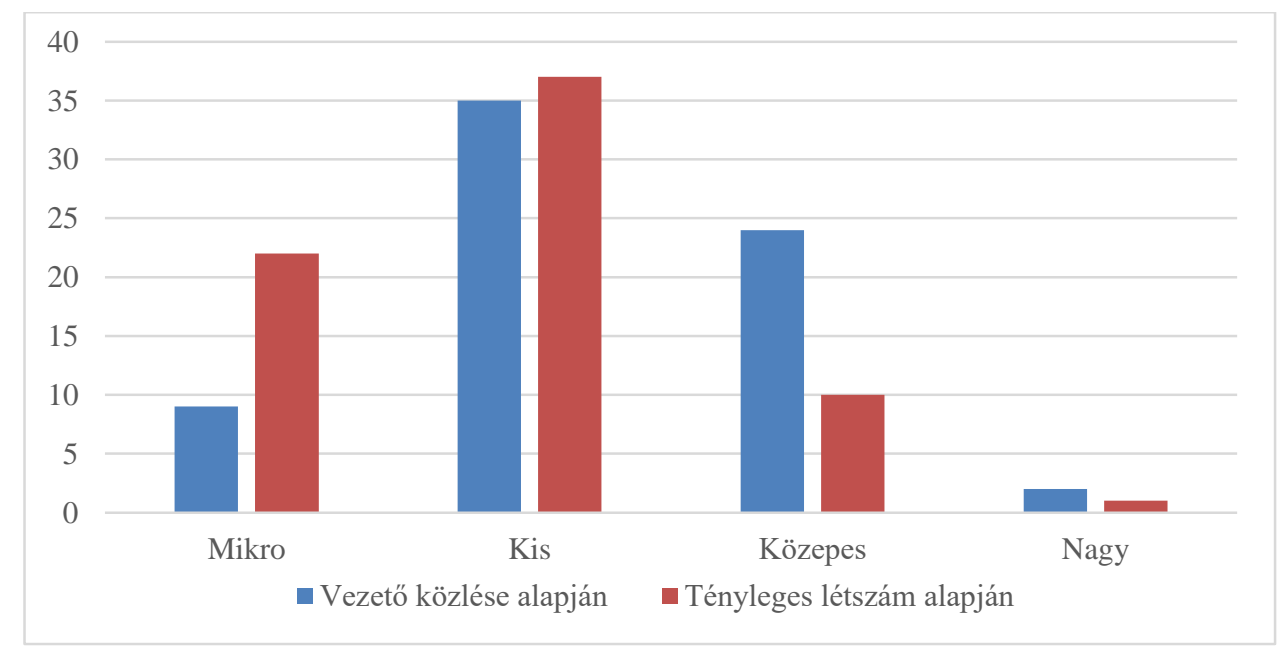

5. ábra. Méretkategória szerinti megoszlás - szubjektív közlés és objektív számítás alapján

A likviditási zavarokat a vállalkozások müködő tőkéjének- nettó forgo tőkéjének függvényében vizsgáltuk. A fizetőképességre vonatkozó könnyen meghatározható mutató a müködő (=forgó) tőke és annak nettósított változata, amelyet Tarnóczi, Fenyves, Vörös (2014) határozott meg. A működő tőke a 
vállalkozás azon vagyonrésze, amely pénzeszközökben, követelésekben, készletekben és egyéb forgóeszközökben testesül meg, a nettó forgó tőke pedig egy vállalat forgóeszközének és rövid lejáratú kötelezettségeinek különbsége, azaz a forgóeszközöknek a rövid lejáratú kötelezettségek által nem fedezett része.

A negatív forgótőke 16 vállalkozásnál volt kimutatható a 2018-as beszámoló adatok alapján, viszont ez - legalábbis a vezetők közlése alapján nem okozott a közelmúltban likviditási gondot mindegyiküknél, csupán a 8 vállalkozás említett ilyen típusú zavarokat. Érdekes, hogy a pozitív nettó forgótőke ellátottság sem garancia a likviditási zavarok elkerülésére, mint ahogyan a 6. ábra is mutatja: az 54 vállalkozásból 19 jelezték a múltbeli fizetőképességra vonatkozó problémákat, amely természetesen jóval kisebb arány, mint a negatív forgótőkével rendelkező vállalkozásoknál.

A vállalkozások menedzsereit kértük, hogy minősítsék a forgótőke ellátottságukat, s ebben az esetben is az általunk számolt tényadatokon nyugvó értékekhez viszonyítottuk a becslésüket, amely sajnos ismét mutatta a saját vállalkozás pénzügyi helyzetének nem kellő alaposságú ismeretét. A 7. ábrán látható, hogy sok esetben a felsőfokú végzettséggel rendelekző menedzserek sem képesek korrekt módon megítélni a vállalkozásuk likviditására vonatkozó vagyoni elemeket és azok összefüggését a kötelezettségeikkel.

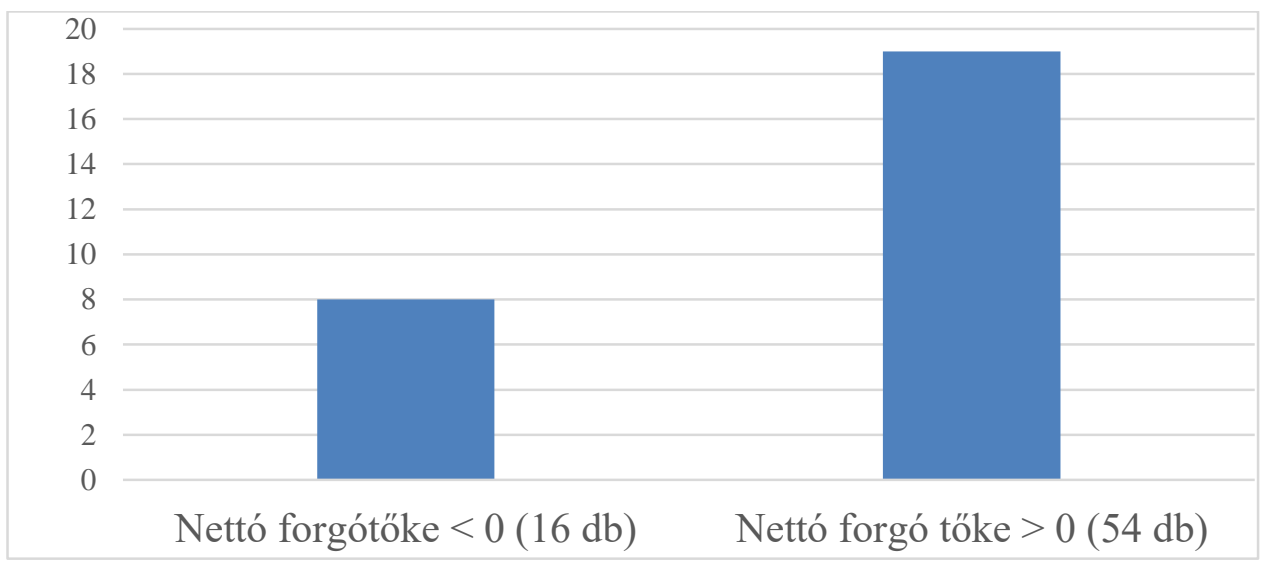

6. ábra Likviditási zavarok említése a nettó forgótőke függvényében

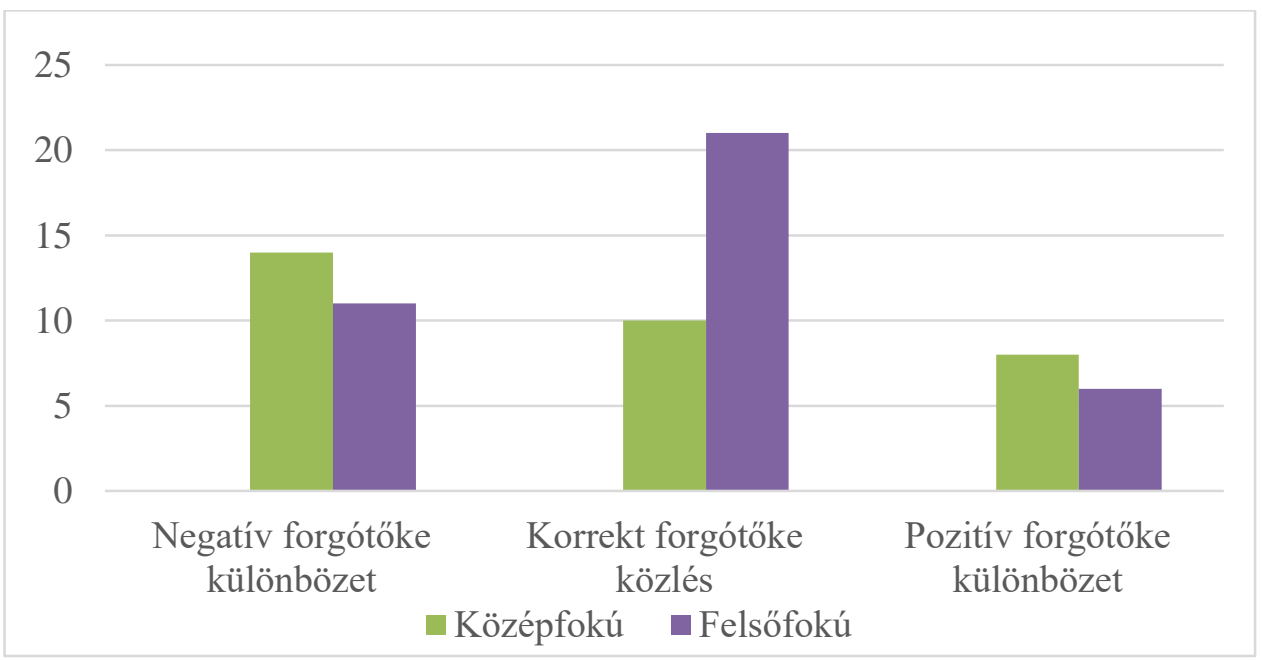

7. ábra. Nettó forgótőkére vonatkozó adatközlés megfelelőssége a végzettség alapján, db 
Kiváncsiak voltunk, hogy a vállakozásuk veszik-e a fáradságot a vevőik minősítésére. Ennek előfeltételeként rákérdeztünk a stratégialilag fontos vevők (=árbevétel jelentős részét adó vevők) számára, amelyet a 8. ábra mutat.

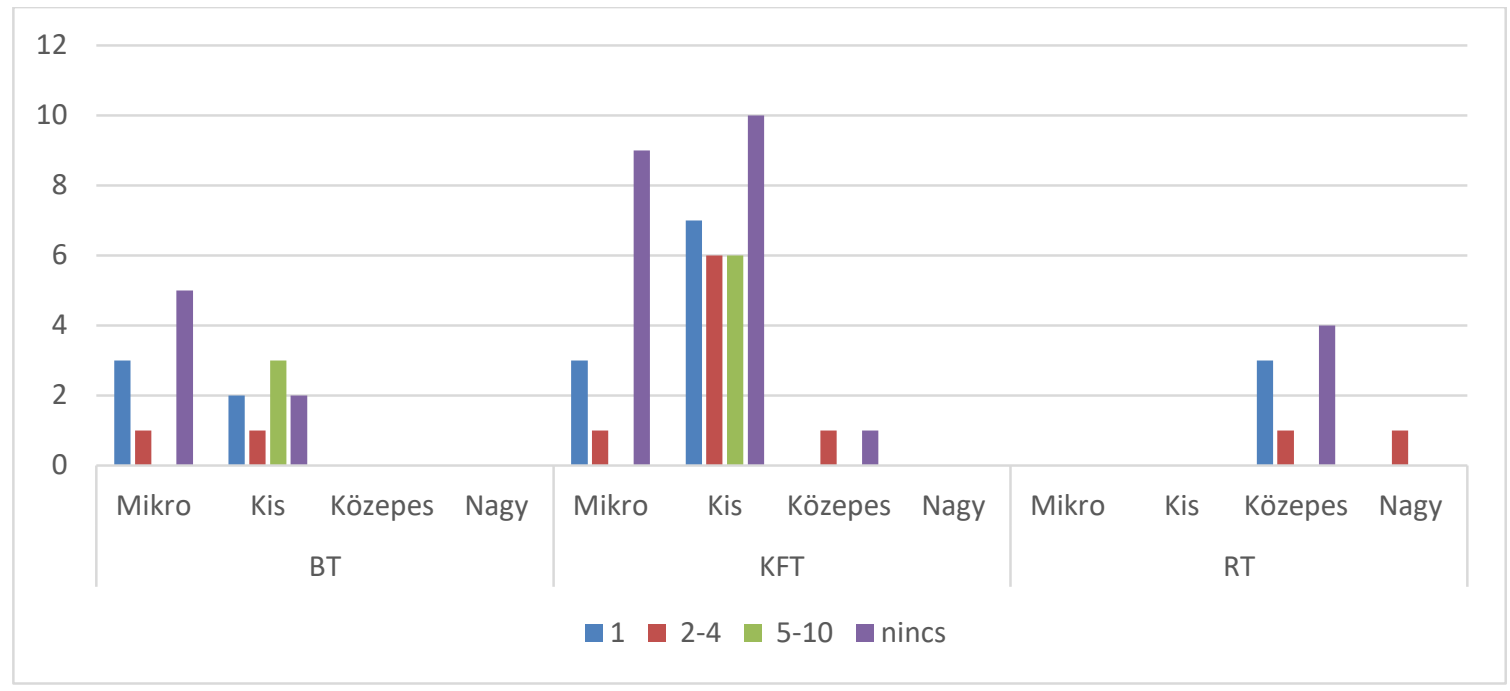

8. ábra gazdasági társasági forma és méretkategória szerinti stratégiainak minősülő vevő́k száma, db

A tevékenységi kör információkkal is összevetve a 8. ábra adatait megállapítható, hogy zömmel a termelő tevékenységet végző vállalkozásokra jellemző az alacsony stratégiai vevőszám és a szolgáltatás jellegű tevékenységeknél van több fontosabb megrendelő vagy olyan nagy a vevőszám, hogy ott már stratégiailag fontosnak egysem minősíthető.

A 9. ábra a vevők minősítésének gyakorlatát mutatja a fentiek alapján az eltérő típusú gazdasági társaságok esetén, ahol kétható, hogy a nagyobb vállalati méretet feltétező társasági formánál nagyobb arányú a vevők értékelésének valamilyen szintű elvégézése.

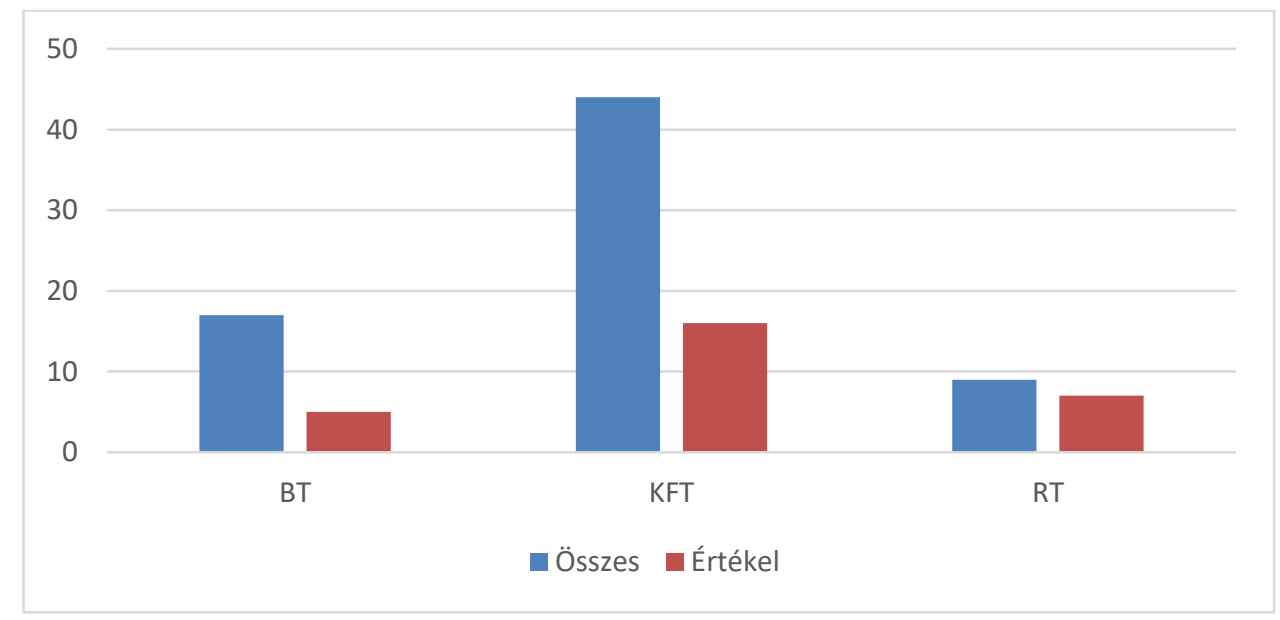

9. ábra A vevők minősítésének előfordulása a társasági forma szerint, db

Következő vizsgálati terület a vállalkozások tervezési gyakorlatához kapcsolódott. Az átfogó vállalkozási tervekkel való ellátottság tekintetében a 10. ábra nyújt információkat a megkérdezettekre vonatkozóan. 


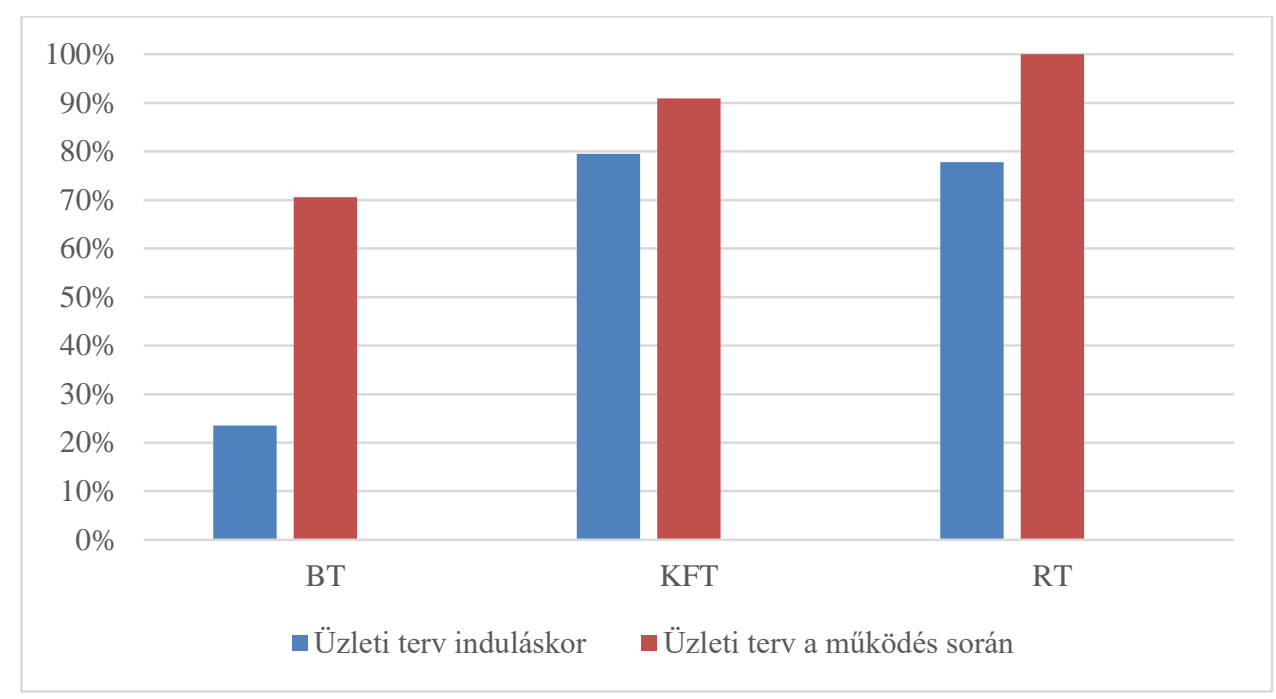

A középtávú tervek készítése összefüggést mutat a vállalati méretkatgóriára is utaló társasági formával, s ez az arány az elmúlt években kimutatottakhoz képest javuló tendenciát mutat, bár nem ugyanaz a vállakozási kör került az elemzésbe.

\section{Összegzés}

A vállalati vezetők igénylik azokat az információkat, amelyekkel a vállalkozás múködése stabillá tehető és ami egyben fejlődési pályát is jelent a vállalkozásnak. Mindezt a vállalkozás controlling - információs rendszere képes biztosítani, amely aktualitásával a menedzserek számára a döntéshozatali folyamatokban a legnagyobb segítséget tudja adni. Ezek gyakorlati megvalósulását szemléltette a 80 vállalkozásban vizsgált fizetőképességi mutatók ismerete és azok szubjektív értékelése a menedzserek által, a tervezési folyamatok tényleges gyakorlata, az önköltségszámítási rendszerek megléte-tervezése részben vállalati méret, részben vállalkozási formák szerint szerinti bontásban. A vizsgálatba vont vállalkozások egyedisége és relatíve kis száma miatt általánosítható összefüggések nem tárhatók fel, de az elemzés szemléletes képet ad a controlling eszközök és módszerek alkalmazására vonatkozóan a vidéki, zömmel mikró-, kis- és középvállalkozási körbe tartozó szervezetek esetén.

\section{Hivatkozások}

[1] B. Horváth, B. Kovács, O. Ella: Vállalkozásokból vállalatok - a kkv-szektor problémái és lehetőségei https://www.penzugyiszemle.hu/tanulmanyok-eloadasok/vallalkozasokbol-vallalatok-a-kkvszektor-problemai-es-lehetosegei

[2] E. Böcskei Az eredménykimutatás tételeinek számviteli és controlling szempontú aspektusai CONTROLLER INFO 8 pp. 10-17. 2013a

[3] E. Böcskei: Qua vadis Controller? - avagy visszatekintve előre haladni CONTROLLER INFO 1 pp. 38. $6.2013 \mathrm{~b}$

[4] V. Fenyves Controllerekel szembeni munkaerôpiaci elvárások vizsgálata CONTROLLER INFO VII : 4 pp. 33-40. , 8 p. 2019 
[5] V. Fenyves - T. Tarnóczi Examination of the expectations of controllers on the labour market CORPORATE OWNERSHIP AND CONTROL 17 : 1 pp. 60-70. , 11 p. 2019

[6] T. Tarnóczi - V. Fenyves - P. Vörös Hagyományos pénzügyi mutatók alkalmazásának problémái a vállalati teljesítmény mérésébenACTA SCIENTIARUM SOCIALIUM 17 : 40 pp. 121-134. , 14 p. 2014

[7] J. Tobak - A. Nagy - K. Pető -V. Fenyves - A. Nábrádi The main factors determining effective operation in case of a family business INTERNATIONAL JOURNAL OF ENTREPRENEURIAL BEHAVIOUR AND RESEARCH 24 : 6 pp. 1065-1074. 2018

[8] Gy. Vadász. https://www.sonline.hu/gazdasag/hazai-gazdasag/a-kormanygazdasagvedelmi-adotervet-dicserte-a-magyar-iparszovetseg-1608404/

[9] M. Veresné Somosi A szervezeti kompetencia- és képességépítés néhány sajátossága CONTROLLER INFO I. : 11. pp. 21-30. , 10 p. 2013

[10] Z. Zéman - Cs. Lentner THE CHANGING ROLE OF GOING CONCERN ASSUMPTION SUPPORTING MANAGEMENT DECISIONS AFTER FINANCIAL CRISIS POLISH JOURNAL OF MANAGEMENT STUDIES $18: 1$ pp. 428-441. , 14 p. 2018 